
\title{
25 Research Square \\ Functional fitness and quality of life of elderly Lian Gong, Tai Chi, and Qigong practitioners
}

Márcia Regina Martinez Tedeschi ( $\square$ marcia.tedeschi@hotmail.com )

Universidade Federal de Sao Paulo Escola Paulista de Enfermagem https://orcid.org/0000-0002-8817-9089

Tatiane Assone

Universidade de Sao Paulo Faculdade de Medicina

Mauro Ferreira

Universidade Nove de Julho

Káren Mendes Jorge de Souza

Universidade Federal de Sao Paulo Escola Paulista de Enfermagem

\section{Research}

Keywords: Aging, Functional Fitness, Body Practices, Quality of Life

Posted Date: July 1st, 2020

DOI: https://doi.org/10.21203/rs.3.rs-38591/v1

License: (c) (i) This work is licensed under a Creative Commons Attribution 4.0 International License. Read Full License 


\section{Abstract \\ BACKGROUND}

Long-term regular physical activity, such as body practices of Traditional Chinese Medicine, seems to be an important habit for maintaining the functional fitness, independence and quality of life of elderly individuals. However, scientific knowledge production concerning assessment of such practices, specifically for the elderly population, focusing on functional fitness and quality of life, is still modest. Moreover, there is a lack of studies with long-term follow-up and control groups. Therefore, this study aims to compare the parameters of functional fitness and the dimensions of quality of life of elderly participants and non-participants in the body practices of Traditional Chinese Medicine. Longer adherence time, shorter adherence time and control group have been considered.

\section{METHODS}

This is an observational epidemiological case-control study carried out with 118 elderly individuals ( $\geq 60$ years). The case group was represented by 59 elderly people practicing the body practices of Traditional Chinese Medicine, and they were subdivided into two groups, according to their median adherence time $(<24$ months and $\geq$ 24 months). The control group was composed of 59 participants who were not participating in physical activity programs or guided body practices. Collection was carried out in four Traditional Medicine Specialized Units of the Municipal Health Office of the city of São Paulo. Sociodemographic and functional variables were collected. Quality of life was measured by Medical Outcomes Study 36-Item Short-Form Health Survey (SF-36). For data analysis, a univariate logistic regression and the Kruskal Wallis test have been performed.

\section{RESULTS}

When assessing quality of life, favorable results were found for the case group, with longer ( $\geq 24$ months) adherence time in the domains of bodily pain $(p=0.003)$, vitality $(p=0.021)$, role emotional $(p=0.034)$, and mental health $(p=0.020)$. A better result was observed in the case group, with longer ( $\geq 24$ months) adherence time in the functional 30-second chair stand test $(p=0.006)$.

\section{CONCLUSIONS}

The body practices of Traditional Chinese Medicine can contribute to quality of life, functional fitness, and lower limb strength.

\section{Background}

The change in the world demographic profile showed a significant increase in the proportion of elderly individuals, and it is one of the most significant themes of the 21 st century. This trend sets up a new epidemiological reality and creates challenges for public policy makers and for the Brazilian health system in terms of ensuring comprehensive care. Thus, the focus is directed to elderly people and their needs, especially those resulting from decreased physical, cognitive, mental/emotional and social autonomy ${ }^{1,2}$. 
Scientific literature emphasizes the importance of actions that encourage and provide elderly individuals with adherence and maintenance of a healthy and physically active lifestyle $e^{3}$ with quality of life $e^{2}$. Regular physical activity, such as the body practices of Traditional Chinese Medicine (BPTCM), seems to be an important habit for maintaining long-term functional fitness, independence and quality of life ${ }^{4}$.

BPTCM are integrative and complementary health practices also called meditative movements, as they include, during their performance, meditation, body movement, breathing, and relaxation ${ }^{5}$. Studies show that such practices have contributed to promoting health and quality of life for elderly individuals ${ }^{6-8}$. There is evidence regarding the association of such practices in reducing stress, anxiety and depression ${ }^{9}$ and in increasing self-efficacy and social support ${ }^{10}$. Moreover, they seem to positively assist in improving physical function, balance and consequently preventing falls ${ }^{11}$.

According to the Brazilian scientific literature, assessment of these practices, specifically for the elderly population, focusing on functional fitness, quality of life, and social support, is still minimal; and it represents a gap in the production of scientific knowledge. There is a lack of studies with long-term follow-up and control groups.

Therefore, this study aims to compare the parameters of functional fitness and the dimensions of quality of life of elderly participants and non-participants in the body practices of guided BPTCM, considering longer adherence time, shorter adherence time, and control group.

The results support the development and implementation of strategies to promote healthy aging. BPTCM are associated with comprehensiveness of care, sensitivity and body awareness, and the opportunity to redefine the ways of dealing with health-disease-care of elderly individuals.

\section{Methods}

This is an observational epidemiological case-control study carried out with 118 elderly people aged 60 years and older; Traditional Medicine Specialized Units (TMSU) of the Municipal Health Office of São Paulo (SMS-SP) users; belonging to Eastern, Central, and Southeastern Regional Health Coordination Centers. TMSU offer a wide variety of service modalities in Integrative and Complementary Practices, including BPTCM, Lian Gong, Qigong, Tai Chi Pai Lin, Tai Chi Chuan, among others ${ }^{13}$.

All elderly users enrolled in one of the four TMSU, who met the eligibility requirements of the cases (a group known to have the outcome) and the controls (a group known to be free of the outcome), with conditions to respond to the research instruments, were invited to participate in the survey.

Of the 183 BPTCM participants, the case group (CA) comprised elderly people of both sexes enrolled in one of the four TMSU, practitioners of only one of the guided BPTCM (at least twice a week for at least six months without interruption $)^{14}$. They could practice physical activity in their leisure time, but without guidance from a professional, totaling 59 participants subdivided into two groups according to their median adherence time $<24$ months and $\geq$ 24 months.

The control group (CO) comprised 59 elderly users of both sexes enrolled in the four TMSU, not participating in guided physical activity programs or BPTCM in or out of the TMSU for at least six months. The eligibility criterion established they could practice physical activity in leisure time, but without guidance. 
CA and CO were paired by sex and age, considering the 1:1 ratio between them, accepting an alpha error of $5 \%$ and power of the test $(1-\beta=80 \%)$.

Sociodemographic data were collected through a questionnaire designed to the objectives of the study. Lower and upper limb strength was assessed by 30 -second chair stand test ${ }^{15}$ and hand grip strength test ${ }^{16}$; lower and upper limb flexibility was measured by sit and reach test ${ }^{17}$, chair stand and reach test, and back scratch test ${ }^{15}$; mobility, speed, agility, and dynamic balance were assessed by 8 -foot up-and-go test ${ }^{15}$.

Health-related quality of life was measured by the Medical Outcomes Study 36- Item Short-Form Health Survey (SF36) ${ }^{18}$. The SF-36 is a multidimensional questionnaire consisting of 36 items that encompass the dimensions of physical and mental health and eight domains, namely: physical functioning, role physical, bodily pain, general health, vitality, social functioning, role emotional, and mental health. To assess the results, a score was assigned to each question, and the values were transformed into a scale from 0 to 100; zero was the least favorable score, and 100 was the most favorable score; each domain was analyzed separately ${ }^{18}$.

Statistical analyzes were performed using the statistical program R 3.3.2. (R Core Team, 2016) ${ }^{19}$, which initially performed a descriptive analysis of the dependent and independent variables using mean, median, minimum and maximum values, standard deviation and absolute and relative frequencies. Univariate Logistic Regression was used to compare CA and CO concerning quality of life and functional tests.

The Kruskal-Wallis test was used to compare CA and CO in relation to less ( $<24$ months), equal or greater ( $\geq 24$ months) practice time, according to quality of life and functional tests. An alpha significance level of $5 \%$ was used in the inferential analyzes.

This study was conducted within the ethical standards of research with human beings. Elderly individuals participated voluntarily after agreeing and signing the Informed Consent Form (ICF). The research project was analyzed and approved by the Research Ethics Committee (REC) of Universidade Federal de São Paulo (Number: $1,207,437)$ and by the SMS-SP REC (Number: 1,237,453).

\section{Results}

The study sample consisted of 118 elderly people, with 59 (50.0\%) cases and 59 (50.0\%) controls. Of the total number of individuals shown in Table 1, most are female ( $91.5 \%$ of cases and $89.8 \%$ of controls); white (35.6\% of cases and $35.6 \%$ of controls); with incomplete elementary education (35.6\% of cases and $55.9 \%$ of controls); married (55.9\% of cases and $47.5 \%$ of controls); and unemployed ( $89.8 \%$ of cases and $83.1 \%$ of controls). Among the diseases mentioned, systemic hypertension ( $\mathrm{SH}$ ) prevailed in $64.4 \%$ of cases and in $72.9 \%$ of controls. There was no statistically significant difference between the cases and controls in relation to sociodemographic variables and reported morbidities. 
Table 1

Comparison of sociodemographic variables and related morbidities between the cases and the controls

\begin{tabular}{|c|c|c|c|c|c|c|c|}
\hline \multirow{2}{*}{$\begin{array}{l}\text { Variable } \\
\text { Sex }\end{array}$} & \multicolumn{2}{|c|}{$\begin{array}{l}\text { Cases } \\
\text { n (\%) }\end{array}$} & \multicolumn{2}{|c|}{$\begin{array}{l}\text { Controls } \\
\text { n (\%) }\end{array}$} & \multicolumn{2}{|c|}{$\begin{array}{l}\text { Total } \\
\text { n (\%) }\end{array}$} & \multirow[t]{2}{*}{ P value } \\
\hline & & & & & & & \\
\hline Male & 5 & $(8.5)$ & 6 & $(10.2)$ & 11 & $(9.3)$ & 0.752 \\
\hline Female & 54 & $(91.5)$ & 53 & $(89.8)$ & 107 & $(90.7)$ & \\
\hline \multicolumn{8}{|l|}{ Skin color/ethnicity } \\
\hline White & 21 & $(35.6)$ & 21 & $(35.6)$ & 42 & $(35.6)$ & 0.485 \\
\hline Black & 15 & $(25.4)$ & 7 & $(11.9)$ & 22 & $(18.6)$ & \\
\hline Asian & 5 & $(8.5)$ & 6 & $(10.2)$ & 11 & $(9.3)$ & \\
\hline Mixed-race & 18 & $(30.5)$ & 23 & $(39.0)$ & 41 & $(34.7)$ & \\
\hline Indigenous & & & 2 & $(3.4)$ & 2 & $(1.7)$ & \\
\hline \multicolumn{8}{|l|}{ Education } \\
\hline None & 1 & $(1.7)$ & - & - & 1 & $(0.8)$ & 0.351 \\
\hline Complete elementary education & 9 & $(15.3)$ & 3 & $(5.1)$ & 12 & $(10.2)$ & \\
\hline Incomplete elementary education & 21 & $(35.6)$ & 33 & $(55.9)$ & 54 & $(45.8)$ & \\
\hline Complete high school & 12 & $(20.3)$ & 11 & $(18.6)$ & 23 & $(19.5)$ & \\
\hline Incomplete high school & 11 & $(18.6)$ & 7 & $(11.9)$ & 18 & $(15.3)$ & \\
\hline Complete higher education & 3 & $(5.1)$ & 4 & $(6.8)$ & 7 & $(5.9)$ & \\
\hline Incomplete higher education & 2 & $(3.4)$ & 1 & $(1.7)$ & 3 & $(2.5)$ & \\
\hline \multicolumn{8}{|l|}{ Marital status } \\
\hline Married & 33 & $(55.9)$ & 28 & $(47.5)$ & 61 & $(51.7)$ & 0.596 \\
\hline Single & 7 & $(11.9)$ & 10 & $(16.9)$ & 17 & $(14.4)$ & \\
\hline Widow(er) & 15 & $(25.4)$ & 11 & $(18.6)$ & 26 & $(22.0)$ & \\
\hline Divorced & 4 & $(6.8)$ & 8 & $(13.6)$ & 12 & $(10.2)$ & \\
\hline Common-law marriage & - & - & 2 & $(3.4)$ & 2 & $(1.7)$ & \\
\hline \multicolumn{8}{|l|}{ Emloyed } \\
\hline Yes & 6 & $(10.2)$ & 10 & $(16.9)$ & 16 & $(13.6)$ & 0.287 \\
\hline No & 53 & $(89.8)$ & 49 & $(83.1)$ & 102 & $(86.4)$ & \\
\hline
\end{tabular}

a Univariate Logistic Regression 


\begin{tabular}{|llllllll|}
\hline Variable & Cases & Controls & Total & P value \\
& $\mathbf{n}(\%)$ & $\mathbf{n}(\%)$ & $\mathbf{n}(\%)$ & \\
\hline Diabetes & & & & & & & \\
\hline Yes & 13 & $(22.0)$ & 21 & $(35.6)$ & 34 & $(28.8)$ & 0.106 \\
\hline No & 46 & $(78.0)$ & 38 & $(64.4)$ & 84 & $(71.2)$ & \\
\hline Hypertension & & & & & & & \\
\hline Yes & 38 & $(64.4)$ & 43 & $(72.9)$ & 81 & $(68.6)$ & 0.322 \\
\hline No & 21 & $(35.6)$ & 16 & $(27.1)$ & 37 & $(31.4)$ & \\
\hline a Univariate Logistic Regression & & & & & & & \\
\hline
\end{tabular}

The median time of adherence to body practices (24 months) was used to subdivide CA into shorter adherence time ( $<24$ months) and longer adherence time ( $\geq 24$ months). Therefore, comparisons of functional parameters and aspects related to quality of life were made between the three groups. In relation to functional tests, there was a better result in CA with longer adherence time ( $\geq 24$ months) in the 30-second chair stand test $(p=0.006)$, when compared to CA with shorter adherence time ( $<24$ months) and the control group (Table 2). 
Table 2

Comparison of performance in functional tests between the cases ( $<24$ months and $\geq 24$ months) and the controls

\begin{tabular}{|c|c|c|c|c|}
\hline & Cases & & Controls & P value* \\
\hline \multirow[t]{2}{*}{ Variable } & $<24$ months $(n=16)$ & $\geq 24$ months $(n=43)$ & $(n=59)$ & \\
\hline & $(\%)$ & $(\%)$ & $(\%)$ & \\
\hline \multicolumn{5}{|l|}{ 8-Foot up and go (s) } \\
\hline Mean & 5.5 & 5.1 & 5.6 & 0.129 \\
\hline Median & 5.2 & 5.1 & 5.4 & \\
\hline Minimum & 4.5 & 3.7 & 3.9 & \\
\hline Maximum & 7.8 & 7.1 & 8.3 & \\
\hline Standard deviation & 0.8 & 0.8 & 1.1 & \\
\hline \multicolumn{5}{|c|}{ 30-Second chair stand (rep) } \\
\hline Mean & 12.9 & 15.6 & 14.3 & 0.006 \\
\hline Median & 13.0 & 15.0 & 14.0 & \\
\hline Minimum & 9.0 & .0 & .0 & \\
\hline Maximum & 16.0 & 23.0 & 33.0 & \\
\hline Standard deviation & 2.0 & 3.8 & 4.8 & \\
\hline Sit and reach (cm) & & & & 0.134 \\
\hline Mean & 21.7 & 25.0 & 21.1 & \\
\hline Median & 23.0 & 26.0 & 19.0 & \\
\hline Minimum & 6.0 & 2.0 & 5.0 & \\
\hline Maximum & 37.0 & 41.0 & 45.0 & \\
\hline Standard deviation & 10.5 & 9.6 & 10.3 & \\
\hline \multicolumn{5}{|c|}{ Chair stand and reach (cm) } \\
\hline Mean & -20.0 & 0.0 & -8.8 & 0.741 \\
\hline Median & -20.0 & 0.0 & -2.5 & \\
\hline Minimum & -20.0 & 0.0 & -29.0 & \\
\hline Maximum & -20.0 & 0.0 & 7.0 & \\
\hline Standard deviation & - & - & 12.8 & \\
\hline \multicolumn{5}{|l|}{ Back scratch (cm) } \\
\hline Mean & -21.9 & -12.7 & -13.2 & 0.075 \\
\hline
\end{tabular}

s: seconds; kg: kilograms; rep: repetitions; *: Kruskall Wallis 


\begin{tabular}{|c|c|c|c|c|}
\hline & Cases & & Controls & P value* \\
\hline Median & -24.0 & -13.0 & -15.0 & \\
\hline Minimum & -42.0 & -42.0 & -40.0 & \\
\hline Maximum & 4.0 & 14.0 & 21.0 & \\
\hline Standard deviation & 14.5 & 13.4 & 13.1 & \\
\hline \multicolumn{5}{|c|}{ Right hand grip strength (kg) } \\
\hline Mean & 23.5 & 25.7 & 23.4 & 0.144 \\
\hline Median & 22.4 & 24.3 & 22.0 & \\
\hline Minimum & 14.3 & 10.0 & 10.3 & \\
\hline Maximum & 33.7 & 56.7 & 45.0 & \\
\hline Standard deviation & 5.4 & 7.5 & 7.9 & \\
\hline \multicolumn{5}{|c|}{ Left hand grip strength (kg) } \\
\hline Mean & 22.5 & 23.9 & 22.3 & 0.213 \\
\hline Median & 22.9 & 23.0 & 20.0 & \\
\hline Minimum & 14.0 & 1.0 & 6.3 & \\
\hline Maximum & 32.3 & 45.7 & 45.6 & \\
\hline Standard deviation & 5.7 & 7.3 & 7.3 & \\
\hline
\end{tabular}

Regarding quality of life, comparing CA and CO, statistically significant differences were found for bodily pain, vitality, role emotional, and mental health (Table 3 ). 
Table 3

Comparison of SF-36 domains between the cases ( $<24$ months and $\geq 24$ months) and the controls

\begin{tabular}{|c|c|c|c|c|}
\hline \multirow[t]{3}{*}{ SF-36 domains } & \multicolumn{2}{|l|}{ Cases } & \multirow{3}{*}{$\begin{array}{l}\text { Controls } \\
(n=59) \\
(\%)\end{array}$} & \multirow[t]{3}{*}{ P value* } \\
\hline & $<24$ months $(n=16)$ & $\geq 24$ months $(n=43)$ & & \\
\hline & $(\%)$ & $(\%)$ & & \\
\hline \multicolumn{5}{|l|}{ Physical functioning } \\
\hline Mean & 56.9 & 71.0 & 62.2 & 0.062 \\
\hline Median & 60.0 & 75.0 & 65.0 & \\
\hline Minimum & 15.0 & 10.0 & 10.0 & \\
\hline Maximum & 90.0 & 100.0 & 100.0 & \\
\hline Standard deviation & 23.6 & 21.4 & 25.3 & \\
\hline \multicolumn{5}{|l|}{ Role physical } \\
\hline Mean & 45.3 & 65.7 & 54.2 & 0.113 \\
\hline Median & 37.5 & 100.0 & 50.0 & \\
\hline Minimum & 0.0 & 0.0 & 0.0 & \\
\hline Maximum & 100.0 & 100.0 & 100.0 & \\
\hline Standard deviation & 31.9 & 41.9 & 40.0 & \\
\hline \multicolumn{5}{|l|}{ Bodily pain } \\
\hline Mean & 43.1 & 67.5 & 56.4 & 0.003 \\
\hline Median & 41.0 & 72.0 & 51.0 & \\
\hline Minimum & 12.0 & 22.0 & 12.0 & \\
\hline Maximum & 100.0 & 100.0 & 100.0 & \\
\hline Standard deviation & 25.4 & 24.7 & 25.9 & \\
\hline \multicolumn{5}{|l|}{ General health } \\
\hline Mean & 58.9 & 71.4 & 66.3 & 0.163 \\
\hline Median & 57.5 & 72.0 & 65.0 & \\
\hline Minimum & 20.0 & 30.0 & 22.0 & \\
\hline Maximum & 97.0 & 100.0 & 100.0 & \\
\hline Standard deviation & 24.3 & 18.1 & 22.3 & \\
\hline \multicolumn{5}{|l|}{ Vitality } \\
\hline Mean & 59.4 & 72.1 & 61.1 & 0.021 \\
\hline
\end{tabular}

SF-36: Medical Outcomes Study Short Form 36; *: Kruskall Wallis 


\begin{tabular}{|c|c|c|c|c|}
\hline \multirow[t]{3}{*}{ SF-36 domains } & \multicolumn{2}{|l|}{ Cases } & \multirow{3}{*}{$\begin{array}{l}\text { Controls } \\
(n=59) \\
(\%)\end{array}$} & \multirow[t]{3}{*}{ P value* } \\
\hline & $<24$ months $(n=16)$ & $\geq 24$ months $(n=43)$ & & \\
\hline & $(\%)$ & $(\%)$ & & \\
\hline Median & 62.5 & 75.0 & 65.0 & \\
\hline Minimum & 0.0 & 10.0 & 5.0 & \\
\hline Maximum & 95.0 & 100.0 & 100.0 & \\
\hline Standard deviation & 27.7 & 18.7 & 21.8 & \\
\hline \multicolumn{5}{|l|}{ Social functioning } \\
\hline Mean & 67.4 & 80.1 & 74.5 & 0.217 \\
\hline Median & 75.0 & 88.0 & 75.0 & \\
\hline Minimum & 0.0 & 25.0 & 13.0 & \\
\hline Maximum & 100.0 & 100.0 & 100.0 & \\
\hline Standard deviation & 28.8 & 23.7 & 26.0 & \\
\hline \multicolumn{5}{|l|}{ Role emotional } \\
\hline Mean & 37.5 & 69.0 & 61.0 & 0.034 \\
\hline Median & 33.0 & 100.0 & 67.0 & \\
\hline Minimum & 0.0 & 0.0 & 0.0 & \\
\hline Maximum & 100.0 & 100.0 & 100.0 & \\
\hline Standard deviation & 40.2 & 38.8 & 42.5 & \\
\hline \multicolumn{5}{|l|}{ Mental health } \\
\hline Mean & 70.0 & 75.7 & 65.4 & 0.020 \\
\hline Median & 76.0 & 80.0 & 64.0 & \\
\hline Minimum & 8.0 & 8.0 & 24.0 & \\
\hline Maximum & 100.0 & 100.0 & 100.0 & \\
\hline Standard deviation & 25.5 & 19.5 & 20.1 & \\
\hline
\end{tabular}

The CA with longer adherence time ( $\geq 24$ months) had a better score in bodily pain $(p=0.003)$, when compared to the CA with shorter adherence time ( $<24$ months) and the control group.

In vitality, the CA with longer adherence time ( $\geq 24$ months) obtained a better score $(p=0.021)$, when compared to co.

Concerning role emotional, CO and the CA with longer adherence time ( $\geq 24$ months) had a better score $(p=0.034)$, when compared to the CA with shorter adherence time (<24 months). 
In mental health, the CA with longer adherence time ( $\geq 24$ months) obtained a better score $(p=0.020)$ when compared to $\mathrm{CO}$.

\section{Discussion}

The results of this study show that the CA with longer adherence time ( $\geq 24$ months) performing BPTCM may have been a contributory factor for the improvement of lower limb strength $(p=0.006)$, assessed by 30 -second chair stand test (SCT).

Tai Chi and Qigong practices have a broad theoretical framework ${ }^{20-22}$, and show positive results regarding increased lower limb strength. This fact was observed in a research that assessed the long-term effects ( $\geq 3$ years) of Tai Chi on lower limb strength of elderly individuals. The survey found better results among Tai Chi practitioners compared to physically inactive elderly individuals, although the assessment methodology was different ${ }^{20}$.

However, in the case of Lian Gong (LG), our findings differ from the research that compared the functional fitness of elderly participants in water based exercise, hiking, and LG. Significant results were found for lower limb strength in relation to hiking, when compared to water based exercise and LG, indicating that LG practice generated the lowest performance result in the $\mathrm{SCT}^{23}$.

Another study on LG, which compared physical fitness and health-related quality of life of practitioners and physically inactive elderly individuals, also found no statistically significant differences between the two groups for lower limb strength. Lower limb strength was assessed by the same test, although the intervention period has been smaller ${ }^{24}$. Such disagreement may be related to the scarcity of studies on LG practice; to the methodological quality of the research; and to the different forms of participant assessment and intervention.

Regarding health-related quality of life, long-term BPTCM, although present in fewer studies ${ }^{25,26}$, may indicate significant changes in their different domains. Proficiency in carrying out movements was achieved over time, promoting greater benefits ${ }^{27}$.

With respect to the results, it was observed that the CA with longer adherence time ( $\geq 24$ months) obtained higher scores in bodily pain $(p=0.003)$, vitality $(p=0.021)$, role emotional $(p=0.034)$, and mental health $(p=0.020)(S F-36$ domains).

Long-term psychosocial and health benefits of Tai Chi and Qigong have been also found in a review study that found pain reduction and improvement in psychological well-being over time ${ }^{28}$. Qigong practitioners with more than five years of adherence from a research, supporting the results of this research, attributed their permanence in practice to maintaining health and recovering from some comorbidity ${ }^{29}$.

Although this study has limitations regarding the causal factor of the results found, such findings may be related to the characteristics of BPTCM. Practicing BPTCM includes synchronization of body movements, breathing, meditative mental state, and relaxation. When such components are carried out concurrently and correctly, there is a wide range of benefits to health, quality of life, and recovery and maintenance of physiological functions. BPTCM are being increasingly used as integrative and complementary approaches to health ${ }^{30}$.

\section{Conclusions}


To briefly summarise, when comparing the parameters of functional fitness and the dimensions of quality of life of elderly participants and non-participants of guided BPTCM, considering longer and shorter adherence to activities and $\mathrm{CO}$, it was found that participation in BPTCM can contribute to improving functional fitness, lower limb strength, and quality of life.

\section{Abbreviations}

BPTCM: body practices of Traditional Chinese Medicine; TMSU: Traditional Medicine Specialized Units; SMS-SP: Municipal Health Office of São Paulo; CA: Case group; CO: Control group; SF-36: Medical Outcomes Study 36- Item Short-Form Health Survey; ICF: Informed Consent Form; REC: Research Ethics Committee; SCT- 30-second chair stand test; LG: Lian Gong

\section{Declarations}

\section{Ethics approval and consent to participate:}

The Ethical Board were approved by the Research Ethics Committee (REC) of Universidade Federal de São Paulo (Number: 1,207,437) and by the SMS-SP REC (Number: 1,237,453), and we obtained signed informed consent from all participants prior to study inclusion.

\section{Consent for publication:}

Not applicable.

\section{Availability of data and materials:}

The datasets used and analysed during the current study are available from the corresponding author on reasonable request.

Competing interests:

The authors declare that they have no competing interests.

\section{Funding:}

The authors received no specific funding for this work.

\section{Authors' contributions:}

Conception, planning, analysis, interpretation and writing of the work: MRMT; Analysis, interpretation and writing of the work: TA; Conception, planning, analysis, interpretation and writing of the work: MF; Conception, planning, analysis, interpretation and writing of the work: KMJS.

\section{Acknowledgements:}


To all elderly individuals that participated voluntarily of this study.

\section{References}

1. Minayo MCS. O imperativo de cuidar da pessoa idosa dependente. Ciênc. saúde coletiva. 2019 Jan; 24(1):247-52.

2. Veras RP, Oliveira M. Envelhecer no Brasil: a construção de um modelo de cuidado. Ciênc. saúde coletiva. 2018 Jun; 23(6):1929-36.

3. Boustros GEH, Morais JA, Karelis AD. Current concepts in healthy aging and physical activity: a viewpoint. J Aging Phys Act. 2019 Mar, 27(5):755 - 61.

4. Lee IM, Shiroma EJ, Lobelo F, Puska P, Blair S, Katzmarzyk PT. Effect of physical inactivity on major noncommunicable diseases worldwide: an analysis of burden of disease and life expectancy. Lancet. 2012 Jul 21;380(9838):219-29.

5. Larkey L, Jahnke R, Etnier J, Gonzalez J. Meditative movement as a category of exercise: implications for research. J Phys Act Health. 2009;6(2):230-8.

6. Martin KR, Druce KL, Murdoch SE, D'Ambruoso L, Macfarlane GJ. Differences in long-term physical activity trajectories among individuals with chronic widespread pain: A secondary analysis of a randomized controlled trial. Eur J Pain. 2019 Sep;23(8):1437-47.

7. Easwaran K, Gopalasingam Y, Green DD, Lach V, Melnyk JA, Wan C,et al. Effectiveness of Tai Chi for health promotion for adults with health conditions: a scoping review of Meta-analyses. Disabil Rehabil. 2020 Feb;18:1-12.

8. Tajik A, Rejeh N, Heravi-Karimooi M, Kia SP, Tadrisi SD, Watts TE. The effects of Tai Chi on quality of life in male older people: A randomized Controlled trial. Complement Ther Clin Pract. 2018 Nov;33:191-6.

9. Zhang S, Zou L, Chen LZ, Yao Y, Loprinzi PD, Siu PM, et al. The effect of Tai Chi Chuan on negative emotions in non-clinical populations: a meta-analysis and systematic review. Int J Environ Res Public Health. 2019 Aug 21;16(17):3033.

10. Lo OY, Conboy LA, Rukhadze A, Georgetti C, Gagnon MM, Manor B, et al. In the eyes of those who were randomized: perceptions of disadvantaged older adults in a Tai Chi trial. Gerontologist. 2018 Dec 13; 20(20):1-10.

11. Sun W, Ma X, Wang L, Zhang C, Song Q, Gu H, et al. Effects of Tai Chi Chuan and Brisk Walking Exercise on Balance Ability in Elderly Women: A Randomized Controlled Trial. Motor Control. 2019 Jan 1;23(1):100-114.

12. Antunes CP, Lagranha DM, Sousa MF, Silva AM, Fraga AB. Revisão sistemática sobre práticas corporais na perspectiva das práticas integrativas e complementares em saúde. Motrivivência. Florianópolis. 2018;30(55):227-47.

13. Prefeitura da cidade de São Paulo. Secretaria Municipal de Saúde da cidade de São Paulo. São Paulo: SMS; c2014. Medicinas Tradicionais, Homeopatia e Práticas Integrativas em Saúde na SMS; [cited 2019 Jul 14]. Available from:

http://www.prefeitura.sp.gov.br/cidade/secretarias/saude/atencao_basica/medicinas_tradicionais/index.php? $p=20382$.

14. Fallon EA, Hausenblas HA, Nigg CR. The transtheoretical model and exercise adherence: examining construct associations in later stages of change. Psychology of Sport and Exercise. 2005; 6(2005):629 - 41. 
15. Rikli RE, Jones CJ. Development and validation of a functional fitness test for community-residing older adults. J Aging Phys Act. 1999;7(2):129-61.

16. Stevens PJ, Sydall HE, Patel HP, Martin HJ, Cooper C, Aihie Sayer A. Is grip strenght good marker of physical performance among community-dwelling older people? J Nutr Health Aging. 2012;16(9):769-43.

17. Canada. Fitness and Amateur Sport. Canadian Standardized Test of Fitness (Cstf) - Operations Manual. 3. ed. Canada; 1987, 20-24.

18. Tradução para o português e validação do questionário genérico de avaliação de qualidade de vida "Medical Outcomes Study 36-Item Short-Form Health Survey (SF-36) [tese]

Ciconelli RM. Tradução para o português e validação do questionário genérico de avaliação de qualidade de vida "Medical Outcomes Study 36-Item Short-Form Health Survey (SF-36) [tese]. São Paulo, SP: Universidade Federal de São Paulo; 1997.

19. R Core Team. A Language and Environment for Statistical Computing: R Foundation for Statistical Computing. Vienna, Austria; 2016.

20. Zhou M, Peng N, Dai Q, Li HW, Shi RG, Huang W. Effect of Tai Chi on muscle strength of the lower extremities in the elderly. Chin J Integr Med. 2016 nov;22(11):861-6.

21. Wolf SL, O'Grady M, Easley KA, Guo Y, Kressig RW, Kutner M. The influence of intense Tai Chi training on physical performance and hemodynamic outcomes in transitionally frail, older adults. J Gerontol A Biol Sci Med Sci. 2006;61(2):184-9.

22. Zurita AR. Efectos del Tai Chi sobre la calidad de vida relacionada con la salud en los mayores. Revista Española de Geriatría y Gerontol. 2010;45(2):97-02.

23. Nunes MES, Santos S. Avaliação funcional de idosos em três programas de atividade física: caminhada, hidroginástica e Lian Gong. Rev Port Cien Desp. 2009;9(2-3):150-9.

24. Azevedo AR, Cavaglieri CR, Vilarta R, Maciel RS, De Martino MMF, Sonati JG. Lian Gong for health promotion: a strategy used in primary health care in Brazil. J Family Med Community Health. 2015;2(6):1-6.

25. Han-Cheol K, II-Myeong K, Sung-Woon K. The long-term effect of Tai Chi exercise on exercise self-efficacy and self-perceived health status in the elderly. Indian Journal of Science and Technology. 2016;9(25):1-8.

26. Chan AW, Lee A, Lee DT, Sit JW, Chair SY. Evaluation of the sustaining effects of Tai Chi Qigong in the sixth month in promoting psychosocial health in COPD patients: a single-blind, randomized controlled trial. Scientific World Journal. 2013; 24(425082):1-11.

27. Wayne PM, Hausdorff JM, Lough M, Gow BJ, Lipsitz L, Novak V, et al. Tai Chi training may reduce dual task gait variability, a potential mediator of fall risk, in healthy older adults: cross-sectional and randomized trial studies. Front Hum Neurosci. 2015;9(332):1-10.

28. Rogers C, Keller C, Larkey LK. Perceived benefits of meditative movement in older adults. Geriatr Nurs. 2010 Jan-Feb;31(1):37-51.

29. Jouper J, Hassmén P, Johansson M. Qigong exercise with concentration predicts health. Am J Chin Med. 2006;34(6):949-57.

30. Livramento G, Franco T, Livramento A. A ginástica terapêutica e preventiva chinesa Lian Gong/Qi Gong como um dos instrumentos na prevenção e reabilitação da LER/DORT. Rev bras saúde ocup. 2010;35(121):74-86. 